\title{
Density and Housing: Comparative Evaluation towards a Residential Quality Index. The Case of Collective Dwellings in Córdoba-Argentina
}

\author{
María Cecilia Marengo1,2 \\ ${ }^{1}$ Research Institute for Housing and Habitat, Faculty of Architecture, Urbanism and Design, National University of Córdoba, \\ Córdoba, Argentina \\ ${ }^{2}$ National Council of Scientific and Technical Research, Buenos Aires, Argentina \\ Email:mcmarengo@gmail.com
}

How to cite this paper: Marengo, M. C. (2017). Density and Housing: Comparative Evaluation towards a Residential Quality Index. The Case of Collective Dwellings in Córdoba-Argentina. Current Urban Studies, 5, 35-53.

https://doi.org/10.4236/cus.2017.51003

Received: February 3, 2017

Accepted: March 5, 2017

Published: March 8, 2017

Copyright $\odot 2017$ by author and Scientific Research Publishing Inc. This work is licensed under the Creative Commons Attribution International License (CC BY 4.0).

http://creativecommons.org/licenses/by/4.0/

\begin{abstract}
The crisis on infrastructure systems, mobility and the demands of service provision in increasingly remote areas with less values of urbanity that result from the dispersed city model, leads to reexamining the consolidated and dense tissues. While presenting a more compact land-use, there should be conditions of urban habitability of higher quality than those in the new undifferentiated and diffuse peripheries. In this context, the research analyzes comparatively different residential proposals of collective dwellings as a function of density. The objective of the work is to evaluate, from an architectural design dimension, significant cases of collective housing built in Córdoba city that offer higher levels of densification in relation to the building environment where they are located. It seeks to identify the advantages in terms of residential quality in the different housing proposals that integrate the cases of study and link it with the density adopted in its design. The methodological approach integrates an evaluation matrix that compares housing complexes with different density values. Analytical dimensions related to urban indicators are selected and others with indicators relating to the design of collective housing. Weighting criteria are used to construct a residential quality index (RQI), and to integrate in a simulation model of the concepts: Density and Residential quality. Finally, the results obtained in this first analytical approach of the problem of study are evaluated new interrogations proposed to advance in the analysis of the different levels of densification that are presented in the proposals and their adequacy.
\end{abstract}

\section{Keywords}

Density, Collective Housing, Residential Quality, Architectural Design 


\section{The Problem of Study in the Context of More Dispersed Pattern on Urban Development}

The research problem is centered on a line of work that intersects two themes: urban development and housing policies, from a perspective that considers residential interventions in physical space, not as isolated factors, but inserted in a context of urban-spatial production, with effects on cities' growth patterns. The housing issue is of interest as a tool that, when designing intervention policies to facilitate access to housing, can at the same time contribute to achieving equity objectives in city growth patterns. It also can attenuate residential segregation (by including different housing types and sizes, and different social profile of the inhabitants) and greater efficiency in the use of existing urban capacities while promoting denser residential environments. From this perspective, research on density (based on the analyses of residential complexes) is the starting point to analyze housing design patterns.

However, the process of growth in Latin American cities in the last decades is far away from a more sustainable city. As numerous researchers have pointed out that the relocation of activities and new private investments in the city-periphery shows a process of urban restructuring that introduces significant changes in the model of occupation and land-use qualitatively different from what is present in the stage of industrialization. New urban extensions are promoted in rural areas, giving rise to a new type of spatial configuration, characterized by its dispersion and urban fragmentation. The limits of the city tend to dissolve due to a more dispersed land use pattern in the borders. The conurbation with the localities of the metropolitan area accentuates and new centralities (as shopping malls, hypermarkets) consolidate in the peripheral areas.

In analyzing urban and metropolitan transformations under the impact of globalization, De Mattos (2001: p. 175) points out that the evidence provided by a large number of researches in different cities in this part of the world, indicates that it has been unleashed a generalized tendency towards expanded and uncontrolled metropolization which is producing urban configurations with diffuse boundaries, and regional extension, with a polycentric and fragmented organization. There is a process of commodification of urban development where the capture of urban surplus value in private form becomes the dominant urbanistic criterion.

Residential developments materialized by the real estate market have a relevant influence on the uncontrolled expansion of the agglomerations that have occurred in the last decades. Common processes are identified in several Latin American cities with physical, social and spatial effects. These include: the intensification of suburban expansion with the development of neighborhoods in low density patterns, the physical fragmentation of urban space as a consequence of the delimitation of boundaries and closure of perimeter in new peripheral residential developments; the increase in socioeconomic residential segregation associated with the territorial scale of the new private developments for high income-sectors, as well as in relation to the malignity and intensity of the phenomenon due to the intensification of social homogenization in historically segre- 
gated areas ${ }^{1}$. In urbanistic terms, the general tendency is the reduction of gross densities in human settlements, with more dispersed patterns of land use ${ }^{2}$.

Since 2001, the Research Institute for Housing and Habitat at Faculty of Architecture, Urbanism and Design at National University of Córdoba has developed studies on the production of residential space and its relation with the growth's dynamics in Córdoba city-Argentina; re-examining the results of the application of land use norms in the physical configuration of the city and the urban form ${ }^{3}$. The main research line is focus on the possibilities that technical decisions on urban planning have, to lead the processes of growth towards a more integrated and sustainable city, and to achieve a greater efficiency in land-uses, to counteract the main dynamics previously mentioned.

In Córdoba city in the period 2001-2010, both the housing interventions developed by the market aimed at high and very high income sectors, as well as public housing policies developed by the State focused on the more vulnerable social sectors, promoted a dispersed model of land occupation, characterized by the decline in gross densities. It resulted in the increase of urbanized area per inhabitant ${ }^{4}$. The paradox of the process is that the extension of the urbanized area does not imply an improvement in the possibilities to access to urban land (or dwelling ${ }^{5}$ ). On the contrary, even in the context of the country's economic growth (such as that took place in Argentina in the first decade of the 21st century $\left.{ }^{6}\right)$, the deficit continues increasing while the city continues expanding. Large population sectors have no possibilities to access to urbanized land (or dwellings) inside the city boundaries. New residential extensions take place in a context where the consolidated neighborhoods that have urban capacity (provision of infrastructure networks, services and equipment) to infill or densify, lose population.

Urban land, as an asset that is subject to appreciation and strong speculation in the market, becomes a scarce commodity if we examine it in terms of the population's access possibilities, impelling a process of de-densification of the urban structure.

\section{Ongoing research}

The crisis on infrastructure systems, mobility and the demands of service provision in increasingly remote areas with less values of urbanity that result from the dispersed city model, leads to reexamining the consolidated and dense tissues. While presenting a more compact land-use, it is assumed that they have conditions of urban habitability of higher quality than those in the new undifferentiated and diffuse peripheries. So, the question is: to what extent it would be 
possible to densify existing areas in the city providing residential quality?

The paper discusses results to address this question observing that density by itself is not enough to achieve residential quality. As density is a considered a relative dimension, urban and architectonical dimensions are integrated in a residential quality index, to approach the problem of building a more livable, sustainable and dense urban form.

The research analyzes comparatively different residential proposals of collective dwellings as a function of density. The objective of the work is to evaluate significant cases of collective housing built in Córdoba that offer higher levels of densification in relation to the building environment where they are place in. It seeks to identify the advantages in terms of residential quality in the different housing proposals that integrate the cases of study and link it with the density adopted in its architectural design.

The collective housing projects are materializing as specific interventions in the urban fabric and are recognized by their significant urban form. They are developed through public policies or by the real estate market in urban renewal neighborhoods.

The concept of density is considered an instrument for planning residential interventions to achieve a more compact urban form, as opposed to the expansion in low density that is the constant present in the new peripheral areas. The questions the research seeks to answer are:

-What are the comparative advantages in terms of the quality of housing in the different collective housing proposals analyzed?

-What relationship do they have with the variable density?

-Which variables of architectural-urban design should be considered in collective housing proposals to promote densification processes with residential quality?

The methodological approach integrates an evaluation matrix that compares collective housing complexes with different density values. Analytical dimensions related to urban indicators are selected and others related to architectural design. Weighting criteria are used to construct a residential quality index, and to integrate in a simulation model the concepts: Density and Residential quality. Finally, the results obtained in this first analytical study are evaluated. New questions are proposed to advance the analysis of the different levels of densification that could be included in future proposals and their degree of adequacy in terms of residential quality.

\section{Density, Some Definitions}

The concept of density-from the perspective of physics and chemistry-is a scalar magnitude that refers to the amount of mass contained in the volume of a substance.

In urban terms, the concept of density is used in urban planning to measures the concentration of population in an area (usually defined in $\mathrm{km}^{2}$ or hectares).

In urban-demographic terms, population density refers to the relation be- 
tween inhabitants per $\mathrm{km}^{2}$ residing in a locality (data generally obtained through the national censuses of population and housing). Is a relevant indicator when one wants to account for the scale of a particular agglomeration or the urban dynamics, both in terms of its historical conformation (its evolution) or the present situation (to characterize it). Population density allows compiling comparisons on the evolution of urban development in different time periods. On a territorial planning scale, population density is used to determine the need to incorporate new urban land, social equipment and infrastructure related to population growth projections.

The processes of urban growth are produced by two different dynamics: by extension of urbanization (associated with the expansion of the city-boundaries and the decrease in gross densities) or by renewal of the urban fabric, modify the occupation patterns by replacing old buildings or increasing densities affecting by new uses (or the intensity of uses).

When refer to planning residential areas or urban design, the concept of density is used in physical-spatial terms to measure the compactness of an area and to identify the number of dwellings units (by hectares) in urban settlements. Gross density indicates the number of dwelling units in an area (that includes other land-uses as urban roads for example) while net density indicates the number of dwelling in a residential plot, measured in dwellings/hectares.

In the case of study net density is calculated in dwellings per hectare and the plot considers only the residential area belong to the housing complexes.

In the last decades of the twentieth century, and as a result of policies aimed at achieving greater sustainability in urban development, interest in compact city theories and policies is emerging. Burgess (2001: p. 51) defines them as attempts to increase constructed area and residential density to intensify urban economics, social and cultural activities and to manipulate urban size, shape, structure and settlement systems in search of the benefits derived from the concentration of functions. In this context, when analyzing the advantages of densification at the urban scale, it is associated with environmental sustainability, that is to say: the reduction of pollutant emissions caused by individual trips and journeys, the reduction of energy consumption, the loss reduction of land for agricultural use; the more efficient use of public transport, the economies of scale that can be achieved in the provision of services and infrastructure, among others.

With the new century, the changes brought about by the globalization of economic activities and the new logics of expansion of urban settlements in the post-Fordist city led to the dissociation of concepts of urban settlements/city. As Malavolta (2007: p. 30) mentions, the density of the compact city is becoming less and less an indispensable prerogative for urban "to take place", as social and material construction, relations, uses and spaces. Other forms of urbanity are already found in contexts of diffuse settlements, which leads to question the uniqueness of the urban condition of the compact city, given that the two conditions of occupation (compact and diffuse) are presented in the same agglomeration. The population residing in a diffused urbanization does not have the cha- 
racteristics of intensity and density that characterize the consolidated city (Indovina, 2004: p. 52). The same author mentions that in a certain phase of urban development the concept of inhabiting was based on a connotation of the city as a collective space. Today this condition has changed and in the analyzes of the current urbanization it is mentioned that, the greater propensity to the movement, the greater accessibility in terms of time and connectivity offered by the technologies of information and communication, would be replacing the traditional concept of city based on population and buildings concentration in urban space.

The average density of a city as a representation of the urban form is an incomplete representation. The way in which individuals and families relate to the city is neither a constant nor a natural determination, but rather a cultural and political product (Indovina, 2004: p. 52).

Density subject is particularly versatile in the interpretation of urban phenomena, allowing the analysis of the transformation actions in the urban-architectural physical-space in different dimensions of approach (Newman, 2005). It is possible to involve density at the urban scale, in normative premises, when considering sectors affected by renovation processes and also consider it in the architectural project, by proposing an occupation index (dwellings/hectares). It is presented as a useful variable when interpreting and measuring the lifestyles implicit in a given organizational model of the residential organization.

The signs of this "meaning" transformation suggest new interpretations in the urban analysis, where density can be an instrument to analyze the fragment and not only be considered as an indicator of the evolution in land uses.

When the analysis is applied to residential tissue, we use the concept of net density, bearing in mind that it is not an absolute measure, but a relative concept. So, the interactions between the variables considered in the analysis-that describe different architectural forms-are useful to explain the relationship between density and the residential quality proposed. In this research we supposed that even if the same density values are present in certain housing complexes, the residential quality conditions may vary according to the design decisions of the spatial organization and other subjective parameters related to the culture and the social acceptance of the levels of densification proposed (related to the preferences of inhabitants on collective/individual housing).

In terms of urban planning the processes of densification are associated with the possibility of optimizing installed urban capacities; improve urban vitality and intensity of uses. In developing cities, and specifically in the case at hand, this approach is interesting as a strategy to promote a more efficient and sustainable city form from the environmental, social and economic point of view, with a model of occupation that contributes to mitigate the impact on infrastructure networks and services by increasing economies of scale ${ }^{7}$.

\footnotetext{
${ }^{7}$ Studies carried in Córdoba (Ramos, 1985) stated a minimum of 100 inhabitants per hectare to support urban development costs, by 2010 the gross density decreased to 50.38 inhabitants per hectare.
} 


\section{The Cases of Collective Housing in Córdoba}

\section{Background}

Results of research carried out on the urban growth process in the city of Córdoba, in two inter-census periods 1991-2001 and 2001-2010 (Marengo, 2015) confirm the increase in urbanized land consumption per inhabitant and the decrease of the gross density in the urban administrative boundaries. When examining the relationship between urbanized area and population, it was observed that the urbanized area increased per inhabitant, even though the inter-census population growth rate decreased. Thus for example, it moved from $130.59 \mathrm{~m}^{2}$ in 1970 ; to $171.34 \mathrm{~m}^{2}$ in $1980 ; 173.82 \mathrm{~m}^{2}$ in 1991 and $205.69 \mathrm{~m}^{2}$ in 2001. Gross density fell from 62.16 inhabitants per hectare in 1991; to 51.52 in the year 2001; and 50.38 in 2010. These values indicate the generalized tendency to de-concentration of the population in the urban limits ${ }^{8}$.

Methodological approach

The growth process that prevails in Córdoba is the extent and a dispersed urban form (Figure 1). The research analyzes collective dwellings that constitute specific cases of densification and atypical situations in the urban tissue due to their compactness and density. The housing complexes were built through public housing policies (for low- and middle-income social sectors) and in the last

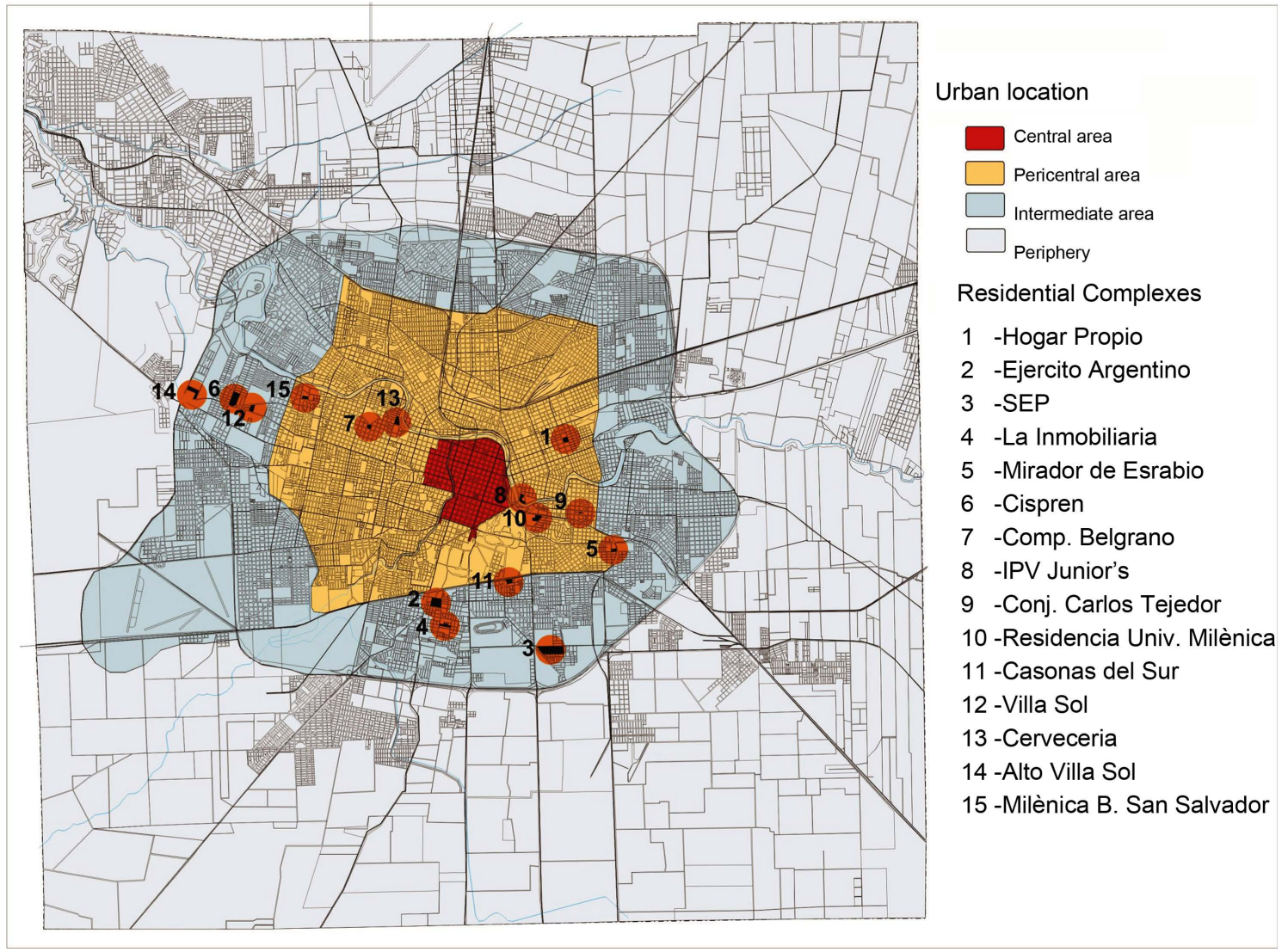

Figure 1. Urban location of case studies in Córdoba city.

${ }^{8}$ Córdoba city has an urban administrative area of 52.000 square kilometers; its boundaries are defined by a square of $24 \mathrm{~km}$ of side, which include rural, industrial and urban uses. 
period, by the real estate market for middle-income social sectors.

The study of these residential complexes comparatively evaluates the residential quality in the different alternatives of spatial organization proposed. It relates the architectural-urban design of the building with densification values. It provides results on the effectiveness of each proposal (based on previously selected variables) as possible models to be replicated in future residential interventions. The study cases include 15 collective housing complexes, of public and private production. They were built over an extended period of time (35 years) from 1976 to 2011, thus present different criteria of spatial organization and conceptions on collective housing, according to the ideas in force in each historical period (Figure 2).

The methodological approach considers in a first stage (which is presented in this article) objective variables. It includes the selection of variables and indicators that make it possible to recognize residential quality values to link it with density. The data survey was systematized through summary records. Subsequently, a matrix was formulated, structured as an analytical-conceptual instrument that allows the cross-linking of indicators in three different scales of analysis: urban, architectural and typological. The data are presented in a graphical language (info-graphics) that facilitates comparative reading (Figure 3).

During the second stage of the research, subjective variables will be included (to inquire about the degrees of satisfaction of the inhabitants). An interview will
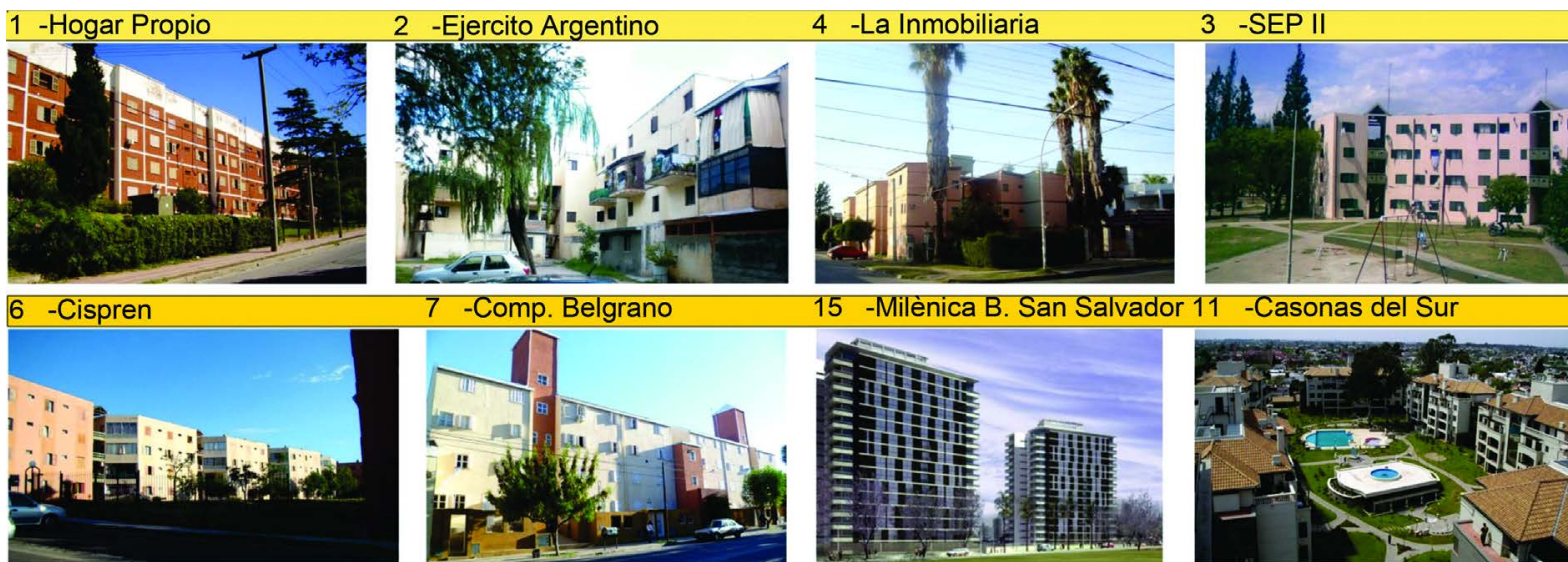

7 -Comp. Belgrano

15 -Milènica B. San Salvador 11 -Casonas del Sur
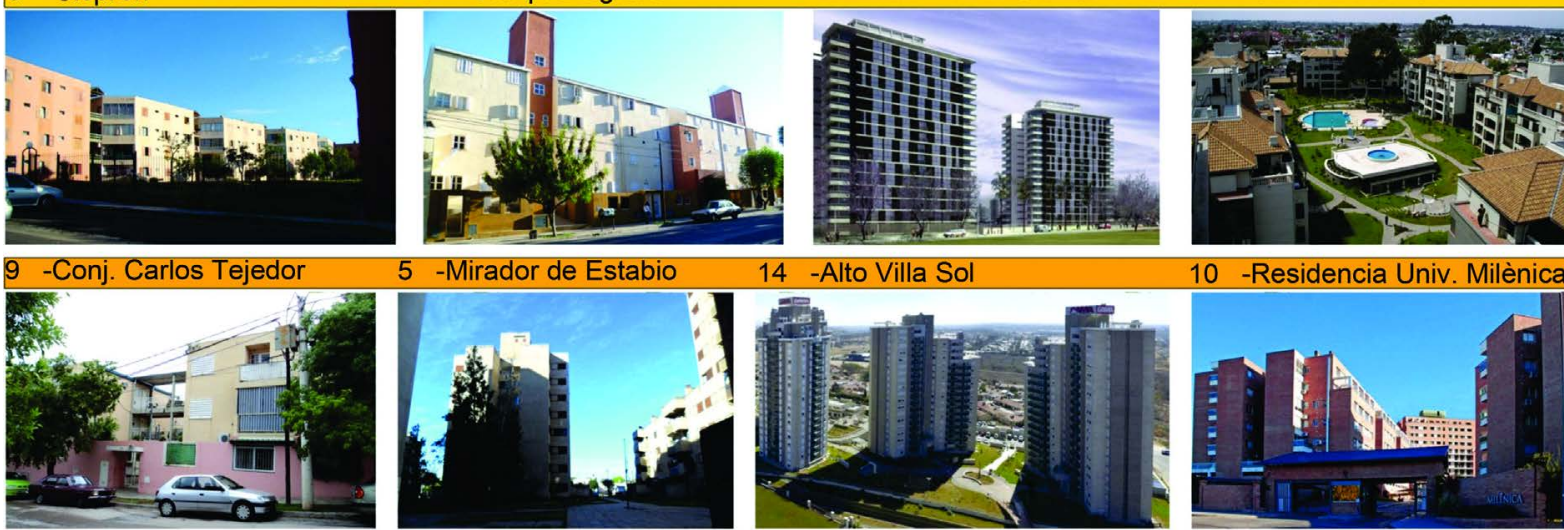

5 -Mirador de Estabio

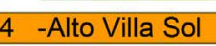

10 -Residencia Univ. Milènica
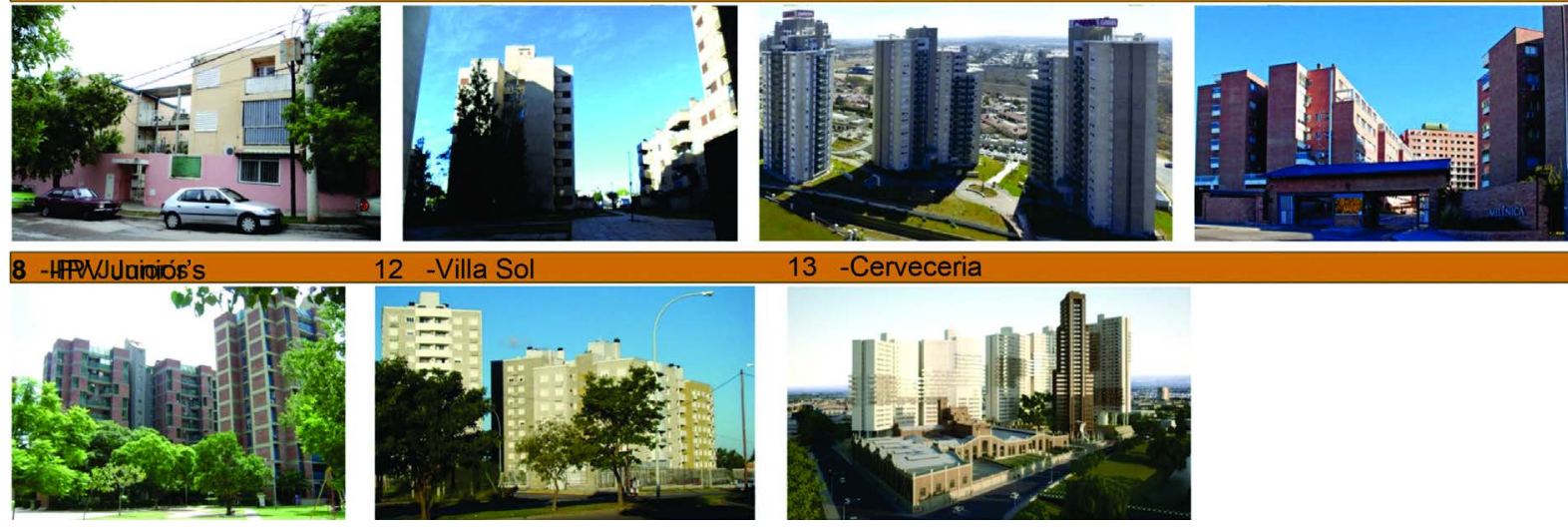

13 - Cerveceria

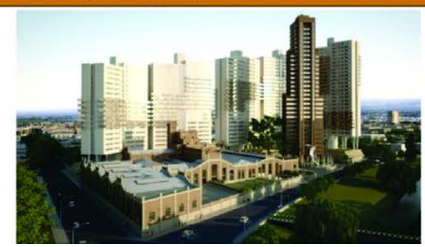

Figure 2. Housing complexes general view. 
be applied to residents to ask about their perceptions about the objective indicators previously analyzed. As to mention: the size of the dwelling, the level of satisfaction with the open and collective areas included in the residential complex; the adequacy of planned parking spaces to social demand, the perception on security, the levels of coexistence between neighbors, the travel time (commuting) they spent each day, the places of provision of services and shops, among others. The results obtained from the subjective approach will be integrated in the model to complex the residential quality index and its relation with density.

Analytical dimensions

At first we considered two scales of approximation: urban and architectural. Six analytical dimensions were analyzed, comparatively weighed and integrated into an equation. A residential quality index was constructed for each of the 15 housing alternatives that integrate study-cases. The results were analyzed in terms of consistency. Finally, the alternatives were compared by linking residential/density quality values; preliminary conclusions were formulated, which feedback the second phase of the research.

Based on the documentary information of each housing complex, we recorded the dimensions of the plots and the number of dwellings. Based on the typological composition of each housing complex, the number of inhabitants was estimated and the net building density (dwelling/hectares) was calculated.

The dimensions considered to address the residential quality of the different residential complexes are as follows:

1. Square meters of residential area per inhabitant. In order to obtain this data, the total amount of built area for own use of the housing unit (without considering common spaces of the building) was computed and divided by the number of inhabitants.

2. Prevision of parking per housing unit, whether they are external or internal (covered or discovered). Data obtained from the information of the projects or data survey in situ. As the housing complexes that integrate the sample correspond to an extensive period of time, there are significant differences in the consideration of this aspect in the architectural-urban design of them.

3. Mobility, measured in terms of the distance (in minutes) from the housing complexes to a central point, in public transport. It was considered the time of the travel in public transport and the time for pedestrian itineraries from the dwelling unit to the bus stop and to the destination in the central point area in the city. Regarding this variable, we asked whether there is any relationship between urban location, building density and distance to the central area.

4. Accessibility, considers the availability of public transport lines in each residential complex. We wondered if the denser are those that have greater accessibility in public transport and if this condition is related to the urban location.

5. Open areas, the dimensions $\left(\mathrm{m}^{2}\right)$ of the open spaces of each proposal were surveyed. An open space value ( $\mathrm{m}^{2} /$ per capita) was calculated. The values of this index were related to density and information about the appropriation, maintenance status and configuration of the spaces was surveyed. 

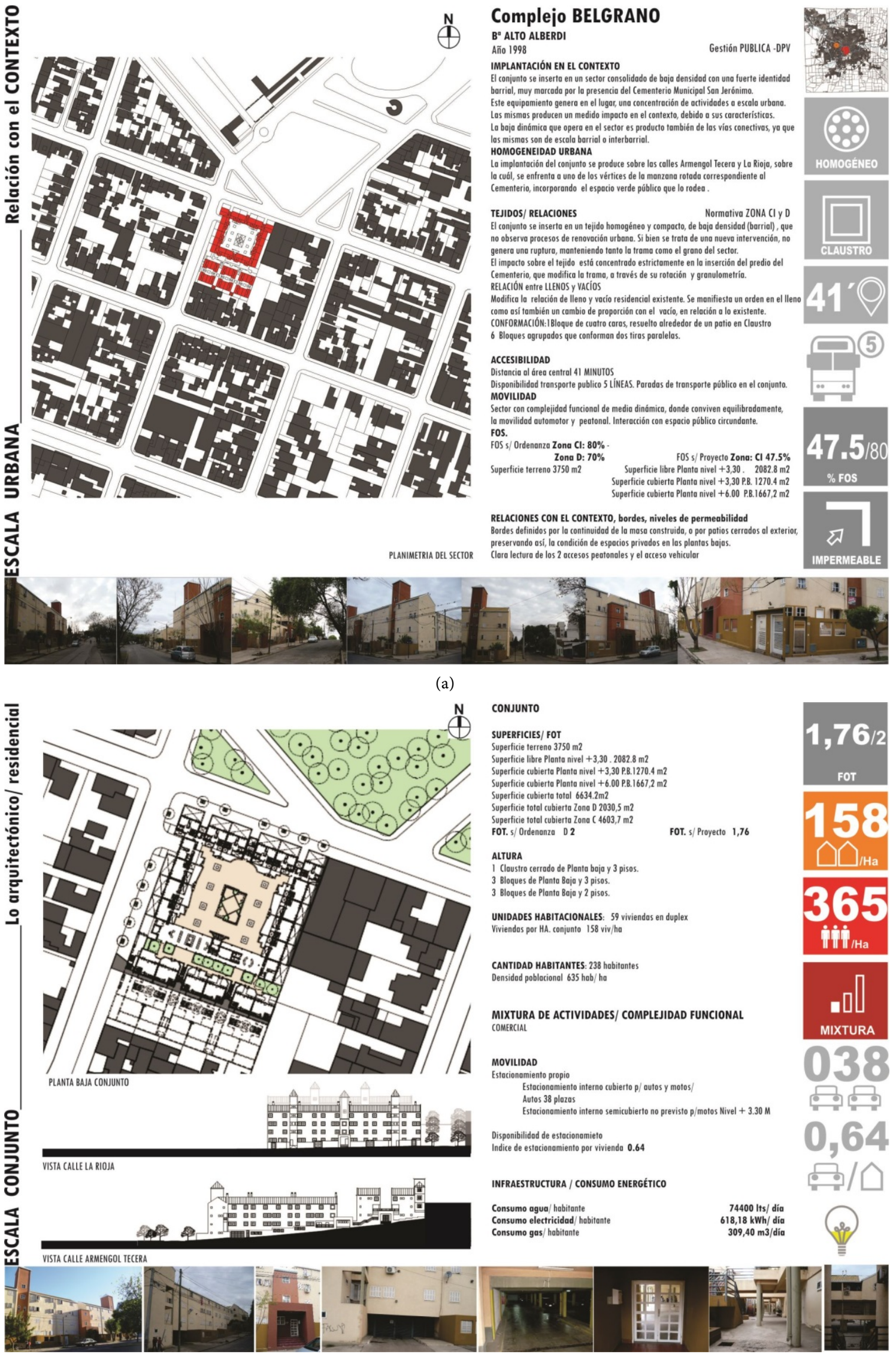

(b) 

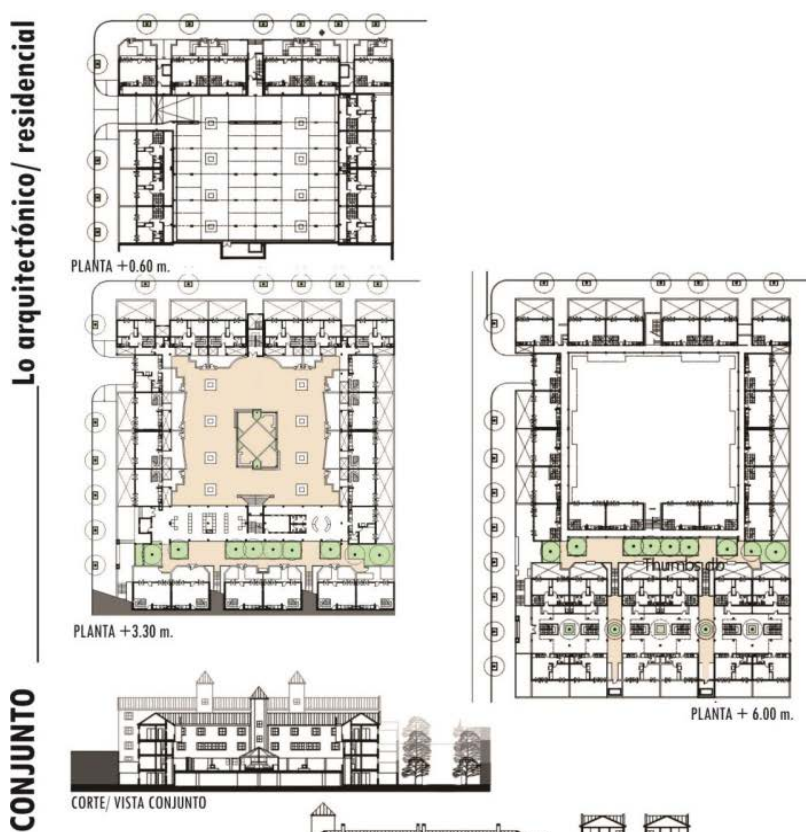

TIPOLOGIAS

DIVESSIDAD TIPOLOGICA Y DIMENSIONAL

TOTAL_ 59 viviendas/ 238 habitantes

8 viviendas/ 14 habitantes
23 viviendas/ DORM 94,60 M2 cantidad__ 28 viviendas/ 146 habitantes

Área POR HABITANTE

DORMI $25,00 \mathrm{~m} 2$ / habitante

DORM $23,25 \mathrm{~m} 2$ / hobitante

J DORM $18.19 \mathrm{~m} /$ / habitante

MIXTURA TIPOLÓGICA

Cloustro cerroda on

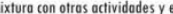

6 Bloque 3/4 pisos hay mínima mixtura tipológico. Tipolgía 10 y duplex de 20 y 30 .

PROPORCIÓN DE MIXTURA Predomina la Tipología de 3 dormitorios

IDORMI $45,00 \mathrm{M} 2 \quad 13 \%$

$\begin{array}{ll}2 \text { DORM } 79,05 \mathrm{M} 2 & 39 \% \\ 3 \text { DORM } 94,60 \mathrm{M2} & 48 \%\end{array}$

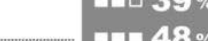

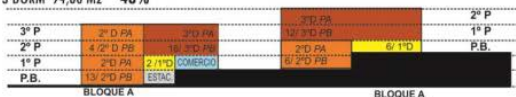

COMBINATORIA TIPOLÓGICA/ SISTEMAS DE MOVIMIENTOS

Acceso peatonal y vehicular a Nivel $+0.60 \mathrm{M}$

Acceso peatonal a Nivel $3,30 \mathrm{M}$

Sistema de movimientos en vertical

Rosca cerrrda 2 núcleos circulatorios verticales (escalero) para acceder a 35 tipologios

verticales (esscalera) para acteder a 24 3̦ipologis

ORGANIZACIÓN TIPOLÓGICA

UNIDAD 2 DORMITORIOS DUPLEX

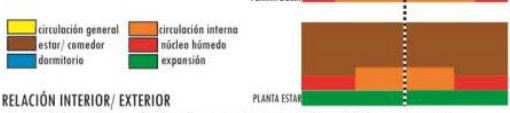

RELACIÓN INTERIOR/ EXTERION

tio centrol a las unidades o a circulaciones

verticales que enlozon a dichos unidades.

se dan a trovés de patios internos que opes

er la tipologia en duplex.

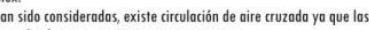
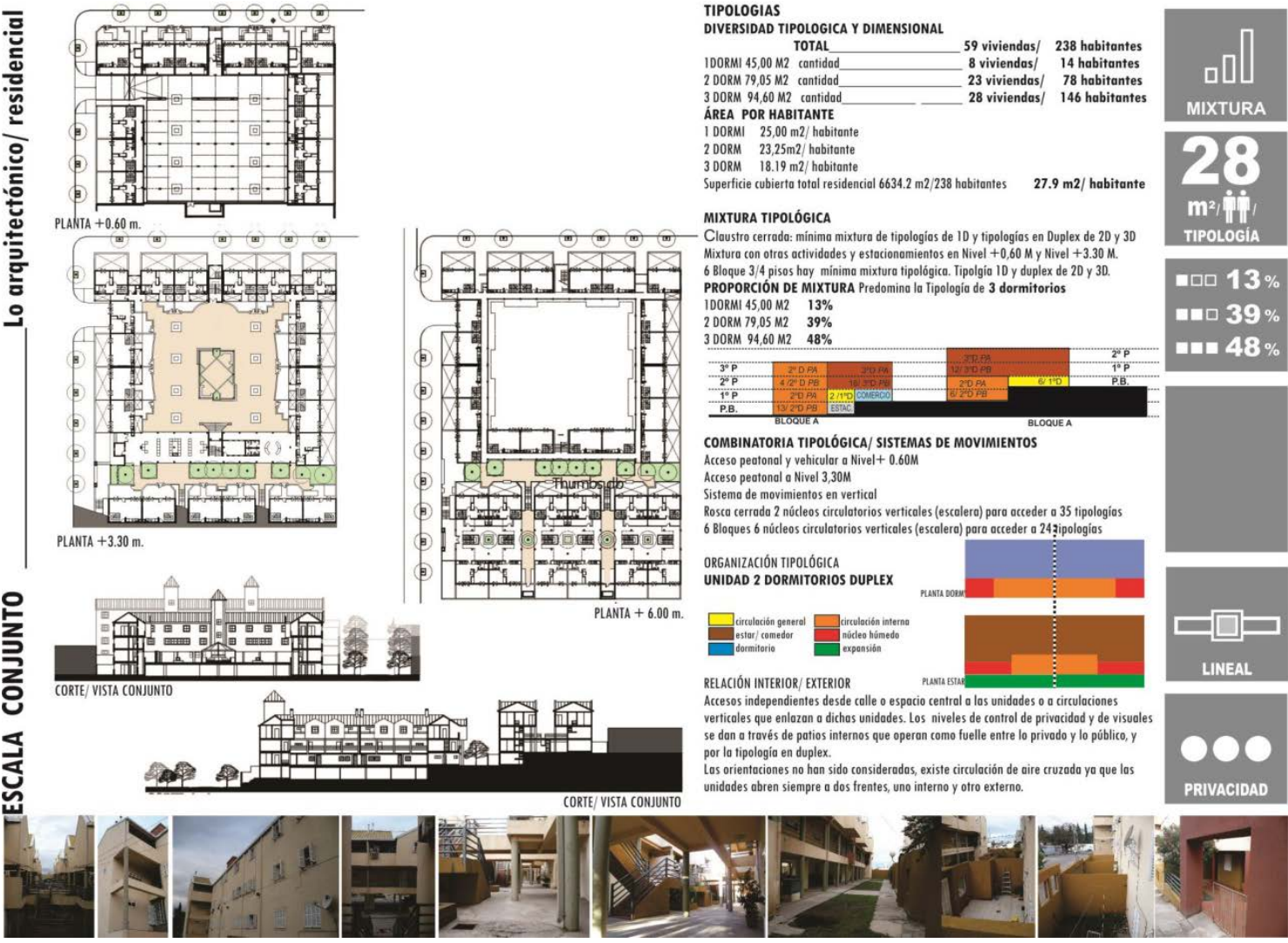

(c)

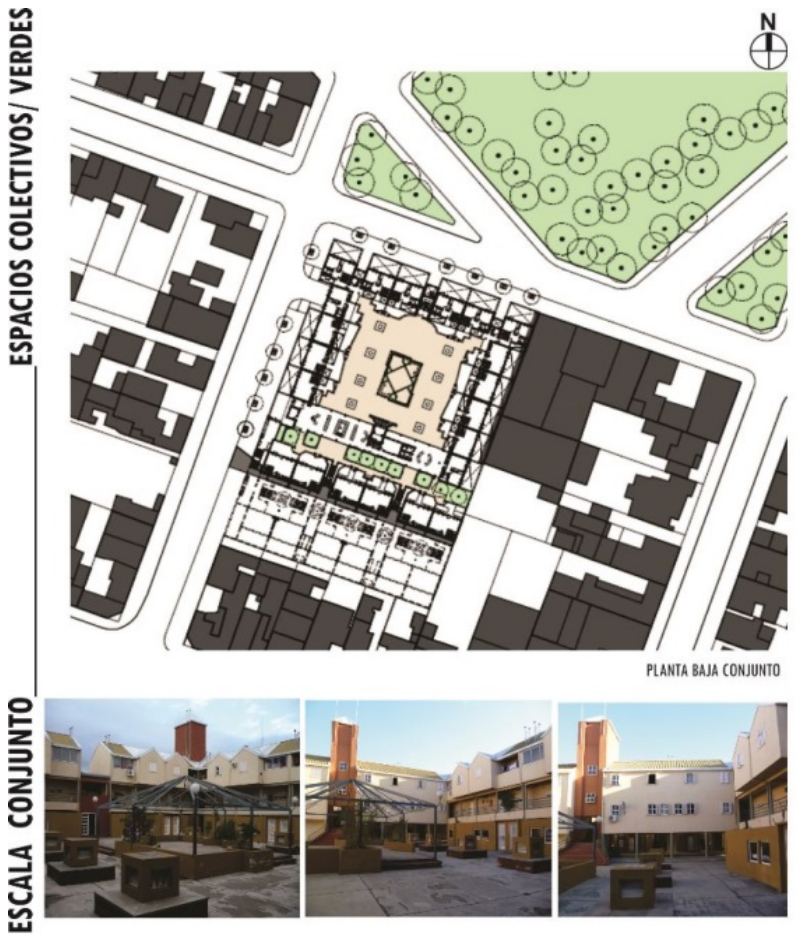

M2 ESPACIO COLECTIVO/ FOS DESAGREGADO

Superficie libre P.B. $2082.80 \mathrm{~m} 2,55,5 \%$ de la superficie totol del terreno

M2 espacio colectivo $x$ habitante $\quad 8,75 \mathrm{~m} 2$

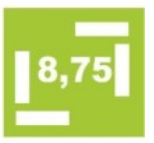

DESTINO

Áreo destinode a sisteme de movimientos ingreso $y$ distribuciones.

pleza seco y espocio verde.

SUPERFICIE ESPACIO COLECTIVO CONSOLIDADO

$\begin{aligned} & 1987 \text { M2 Piso Consolidado } \\ & \text { SUPERFICIE TOTAL } 1987 \text { M2 }\end{aligned} \quad 8.35$ M2 $\times 2$ habitante

SUPERFICIE ESPACIO VERDE

INDICE ESPACIO VERDE

96 M2 Verde

$0,40 \mathrm{M} 2 \times$ habitante

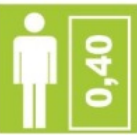

ORGANIZACIÓN Y CONFIGURACIÓN

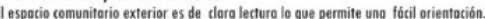

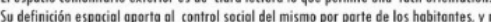
tanto a su apropicción, ya que por su configuración se constituye más en un espocio de distribución y no en un espacio de permanencio

RELACIÓN CON ÁREA RESIDENCIAL.

政 unidades que configuran el conjunte.

rio con las unidades de planta beja, esta filtrado a las unidades, permitiendo a dichas unidades, olguin nivel de

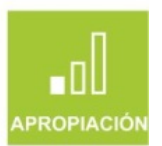

(d)

Figure 3. (a) Illustrates the matrix developed in the case of Ex. \#7: Complejo Belgrano-Urban dimension. (b) Illustrates the matrixin the case of Ex. \#7: Complejo Belgrano-Architectural Dimension. (c) Illustrates the matrix in the case of Ex. \#7: Complejo Belgrano. Typological dimension. (d) Illustrates the matrix developed in the case of Ex. \#7: Complejo Belgrano. Open areas. 
6-Green area per inhabitant, were calculated to be able to comparatively evaluate if incidence in the quality of the different housing complexes, and to have a reference with the values recommended internationally.

Table 1 describes the housing complexes. Table 2 shows the values obtained

Table 1. Main data and density values for housing complexes. Sources: Plans and projects presented in technical planning offices, and on-site surveys. Own elaboration.

\begin{tabular}{|c|c|c|c|c|c|c|}
\hline$\#$ & DATA & & PLOT & DWELLINGS & INHABITANTS & DENSITY \\
\hline & Name of housing complex & Year & Area (hectares) & Number of dwellings & Number of inhabitants & Dwellings/hectares \\
\hline 1 & Hogarpropio & 1976 & 11.831 & 112 & 381 & 95 \\
\hline 2 & Ejercito Argentino & 1978 & 48.500 & 433 & 1.894 & 89 \\
\hline 3 & SEP & 1981 & 145.514 & 841 & 3.554 & 58 \\
\hline 5 & Mirador de Estabio & 1982 & 9.340 & 204 & 811 & 218 \\
\hline 6 & CISPREN & 1996 & 12.873 & 150 & 648 & 116 \\
\hline 4 & La inmobiliaria & 1997 & 8.137 & 60 & 192 & 73 \\
\hline 7 & Comp. Belgrano & 1998 & 3.750 & 58 & 236 & 158 \\
\hline 8 & IPV Juniors & 1989 & 13.350 & 444 & 1.320 & 333 \\
\hline 9 & Conj. Carlos Tejedor & 2001 & 1.922 & 42 & 204 & 218 \\
\hline 11 & Casonas del Sur & 2001 & 16.500 & 220 & 670 & 133 \\
\hline 10 & Residencia Univ. Milénica & 2005 & 19.967 & 534 & 1.215 & 268 \\
\hline 12 & Villa Sol & 2005 & 23.181 & 834 & 2.387 & 332 \\
\hline 14 & Altos Villa Sol & 2005 & 41.312 & 1.064 & 2.886 & 258 \\
\hline 13 & Cerveceria & 2011 & 21.655 & 1.081 & 2.837 & 499 \\
\hline 15 & Milénica B. San Salvador & 2011 & 11.900 & 178 & 616 & 150 \\
\hline
\end{tabular}

Table 2. Values of analytical dimensions of housing complexes Sources: Plans and projects presented in technical planning offices, and on-site surveys. Own elaboration.

\begin{tabular}{|c|c|c|c|c|c|c|c|}
\hline & DIMENSIONS & 1 & 2 & 3 & 4 & 5 & 6 \\
\hline$\#$ & & RESIDENTIAL AREA & PARKING SPACES & MOBILITY & ACCESSIBILITY & OPEN AREAS & GREEN AREAS \\
\hline & Name of housing complex & M2/inhabitants & Parking/housing index & $\begin{array}{c}\text { Distance in } \\
\text { minutes }\end{array}$ & $\begin{array}{c}\text { Public Transport } \\
\text { lines }\end{array}$ & M2/inhabitants & M2/inhabitants \\
\hline 1 & Hogarpropio & 21.50 & 0.41 & 36 & 4 & 25.5 & 22.9 \\
\hline 2 & Ejercito Argentino & 12.50 & 0.18 & 28 & 5 & 19.5 & 18 \\
\hline 3 & SEP & 18.90 & 0.18 & 51 & 4 & 35.4 & 31.5 \\
\hline 5 & Mirador de Estabio & 17.50 & 0.21 & 47 & 4 & 8.35 & 4.58 \\
\hline 6 & CISPREN & 15.00 & 0.4 & 51 & 5 & 15.9 & 13.8 \\
\hline 4 & La inmobiliaria & 15.30 & 0.93 & 47 & 6 & 34.8 & 23.45 \\
\hline 7 & Comp. Belgrano & 27.90 & 0.64 & 41 & 5 & 8.75 & 0.4 \\
\hline 8 & IPV Juniors & 19.50 & 0.2 & 45 & 3 & 7.92 & 7.52 \\
\hline 9 & Conj. Carlos Tejedor & 13.90 & 0 & 39 & 4 & 4.78 & 3.87 \\
\hline 11 & Casonas del Sur & 25.00 & 0.7 & 42 & 5 & 16.5 & 10.1 \\
\hline 10 & Residencia Univ. Milénica & 21.00 & 0.68 & 35 & 6 & 11.25 & 2.75 \\
\hline 12 & Villa Sol & 21.00 & 0.61 & 47 & 3 & 8.06 & 2.73 \\
\hline 14 & Altos Villa Sol & 23.00 & 0.97 & 54 & 4 & 12 & 8 \\
\hline 13 & Cerveceria & 23.00 & 0.4 & 34 & 4 & 14.5 & 4.57 \\
\hline 15 & Milénica B. San Salvador & 29.00 & 1.1 & 45 & 3 & 16.8 & 6.5 \\
\hline
\end{tabular}


for each of the dimensions ( 1 - 6) considered.

The comparative analysis of the values obtained in each housing complex set shows a great dispersion in each analytical dimension (see Table 2). It shows the absence of common criteria in the urban-architectural design. For example, when analyzing:

1. Square meters of residential area per inhabitant: the range of values is between 12.5 to $29 \mathrm{~m}^{2}$ per inhabitant. The lowest values are recorded in those complexes materialized through public policies for low-income population built during the twentieth century (Ex. \# 2 Ejército Argentino, Table 2) and the highest values, for those built by the private sectors to high income inhabitants (Ex. \# 15 Milénica, Table 2). The median value is $21 \mathrm{~m}^{2} /$ inhabitants. A value that is surpassed in all complexes built by private sector in the last decades, and only in two cases built by public funds (Ex. \# 1 Hogar Propio and \# 7 Complejo Belgrano, Table 2).

2. Prevision of parking per housing unit: values ranging from 0 to 1.1 parking areas per dwelling (the median value is 0.41 ). This indicator shows a great dispersion over time, with low values being observed in the case of the older complexes (constructed through public housing policies) with respect to the values provided by the privately-built complexes in the last decade. The increase in the forecast of values of parking areas accompanies the evolution in the motorization indexes of the population in Córdoba city 9 . In the survey carried out, it was observed that one of the most significant modifications in the design is the incorporation of parking garages to attend to the lack of forecast of parking lots.

3. Mobility: The time of displacement at the same point in the central area varies between 28 to 54 minutes. (The median value is 45 minutes). The study cases that integrate the sample have different locations the urban structure, some next to the central areas, others in peripheral areas. There are different accessibility conditions, some are located on transport corridors and others are not. There is no direct correlation between this variable and density.

4. Accessibility: The number of transport lines, has a range from 3 to 6 , (the median value is 4 ) is not related to the density of the housing complexes but to the urban-structures characteristics where they are located (on transport corridors or neighborhoods).

5. Open areas: the values are in a range between $4.78 \mathrm{~m}^{2}$ to $25.5 \mathrm{~m}^{2}$ per inhabitant (the value of the median is: $14.5 \mathrm{~m}^{2} /$ inhabitants). This dimension is significant in all cases, although for different reasons, in those areas where the dimensions of the dwelling area are reduced (public housing units), the exterior space is the main extension of residential activities; in private partnerships, is a distinctive feature of the residential offer (as a leisure area, with equipment to develop recreational and sports activities).

6. Green areas per inhabitant: they vary from 0.4 to $31.5 \mathrm{~m}^{2}$ (The value of the median is $7.52 \mathrm{~m}^{2} /$ inhabitants). Some public complexes present critical conditions due to the low values green areas, while in others the low degree of main${ }^{9}$ There is an increase in the rate of motorization in the city. The values increase from 0.52 cars per household in 1991 to 1.35 in 2010 in Marengo, M. Cecilia (2015). 
tenance conditions the appropriation and use by the inhabitants.

\section{How to Integrate Density and Residential Quality?}

In order to integrate the six dimensions described above into an index, which allows us to compare relative values of residential quality in the analyzed cases and to link it with density, we test different hypotheses. A relative value was assigned to each dimension to weight the incidence of the different analytical dimensions in the final equation. Different tests were carried out to verify the consistency of the results obtained, given the large dispersion in the values of the series that had to be integrated in the residential quality index (RQI $)^{10}$.

The relative value assigned to the variables in the final result represents a first positioning in relation to the importance assumed by the different variables in what is considered "residential quality". Although it is a hypothetical construction, it allows to establish a comparative reading of the housing complexes in terms of quality and to relate it with density.

In this weighting, it was assumed that the variable with the highest incidence in order to reach a high degree of "residential quality" was the availability of own use surface inside the dwelling, which was assigned a $45 \%$ incidence on the total $(100 \%)$; second, the availability of open space for common use by the residents in the complex, which compensates for a reduced area for own use in dwellings, which was assigned an incidence of $20 \%$ (integrating the dimensions of open spaces and green areas in $\mathrm{m}^{2}$ per inhabitant).

In third place in the weighting, was assigned to daily displacement times, given the differences in terms of location of the housing complexes in the urban structure, it was hypothetically considered that a greater distance to the center may negatively affect residential satisfaction (15\%).

Finally, the dimensions of parking rates per dwelling and number of public transport lines were considered with equal incidence value (10\%).

The residential quality equation was formulated as follows ${ }^{11}$ :

$$
\mathrm{RQI}=[(\mathrm{V} 1 \times \mathrm{P} 1) \times \mathrm{I} 1]+[(\mathrm{V} 2 \times \mathrm{P} 2) \times \mathrm{I} 2]+\left[\left(\mathrm{V}^{n} \times \mathrm{P}^{n}\right) \times \mathrm{I}^{n}\right],
$$

where $\mathrm{V}$ is value of the variable; $\mathrm{P}$ is the weight of the indicator over the total considered, I is the positive or negative weight of the variable. The theoretical maximum value for a positive variable is " 1 " and for the negative it is " 0 ". The maximum value that can theoretically be reached in the model is 0.85 . This condition would occur in the case that one of the residential complexes considered in the analysis reached the optimum value in all the variables considered in the simulation. As stated in the following equation:

RQI for this hypothesis is: $0.45 \times 1+0.2 \times 1+0.1 \times 1-0.15 \times 0+0.1 \times 1=$ 0.85 [being the decimal factors the incidents (weights) previously established]

\footnotetext{
${ }^{10}$ To expand on this aspect refer to: Marengo, M. C., Ochoa, A., \& Ambrosini, A. (2015) “Comparative evaluation of indicators of density and residential quality in collective housing complexes" in Proceedings X Biennial of the Colloquium of Territorial Transformations.

${ }^{11}$ Partially presented in 2nd Meeting of Investigators that studies Córdoba City. Marengo, M. C., Ochoa, A., \& Ambrosini, A. (2015).
} 
Based on this development, the following residential quality values (RQV) obtained in the respective housing complexes were the following (Table 3):

It is observed that no housing complex reaches the theoretical maximum value of the RQI defined in 0.85 .

Note the case of Example \# 15 ("Milenica San Salvador") and \# 7 ("Complejo Belgrano") where the higher RQI were obtained: 0.53 and 0.49 respectively (Table 4).

The housing complexes were built in different years, one by private management (\# 15) and the other (\# 7) through public housing policy. In size they are different, in a case composed by 178 dwellings (in two towers of 17 floors) and

Table 3. Values of the residential quality index (RQI) in the housing complexes analyzed. Own elaboration.

\begin{tabular}{|c|c|c|c|c|c|c|c|}
\hline \# & DATA & & PLOT & DWELLINGS & INHABITANTS & DENSITY & RQI \\
\hline & Name of housing complex & Year & Area (hectares) & Number of dwellings & Number of inhabitants & Dwellings/hectares & Valor max. (0.85) \\
\hline 1 & Hogarpropio & 1976 & 11.831 & 112 & 381 & 95 & 0.47 \\
\hline 2 & Ejercito Argentino & 1978 & 48.500 & 433 & 1.894 & 89 & 0.32 \\
\hline 3 & SEP & 1981 & 145.514 & 841 & 3.554 & 58 & 0.43 \\
\hline 6 & CISPREN & 1996 & 12.873 & 150 & 648 & 116 & 0.29 \\
\hline 4 & La inmobiliaria & 1997 & 8.137 & 60 & 192 & 73 & 0.46 \\
\hline 7 & Comp. Belgrano & 1998 & 3.750 & 58 & 236 & 158 & 0.49 \\
\hline 8 & IPV Juniors & 1989 & 13.350 & 444 & 1.320 & 333 & 0.26 \\
\hline 11 & Casonas del Sur & 2001 & 16500 & 220 & 670 & 133 & 0.47 \\
\hline 10 & Residencia Univ. Milénica & 2005 & 19967 & 534 & 1215 & 268 & 0.43 \\
\hline 12 & Villa Sol & 2005 & 23.181 & 834 & 2.387 & 332 & 0.39 \\
\hline 14 & Altos Villa Sol & 2005 & 41.312 & 1.064 & 2.886 & 258 & 0.38 \\
\hline 13 & Cerveceria & 2011 & 21.655 & 1.081 & 2.837 & 499 & 0.44 \\
\hline 15 & Milénica B. San Salvador & 2011 & 11.900 & 178 & 616 & 150 & 0.53 \\
\hline
\end{tabular}

Table 4. Housing complexes \# 15 and \# 7 higher RQI values. Own elaboration.

\begin{tabular}{|c|c|c|c|c|c|c|c|}
\hline$\#$ & DATA & & PLOT & DWELLINGS & INHABITANTS & DENSITY & RQI \\
\hline & $\begin{array}{c}\text { Name of housing } \\
\text { complex }\end{array}$ & Year & Area (hectares) & Number of dwellings & $\begin{array}{l}\text { Number of } \\
\text { inhabitants }\end{array}$ & Dwellings/hectares & \\
\hline 7 & Comp. Belgrano & 1998 & 3.750 & 58 & 236 & 158 & 0.49 \\
\hline \multirow[t]{4}{*}{15} & $\begin{array}{l}\text { Milénica B. San } \\
\text { Salvador }\end{array}$ & 2011 & 11.900 & 178 & 616 & 150 & 0.53 \\
\hline & & RESIDENTIAL AREA & PARKING SPACES & MOBILITY & ACCESSIBILITY & OPEN AREAS & GREEN AREAS \\
\hline & DIMENSIONS & 1 & 2 & 3 & 4 & 5 & 6 \\
\hline & Indicators & M2 /inhabitants & $\begin{array}{l}\text { Parking/housing } \\
\text { index }\end{array}$ & Distance in minutes & $\begin{array}{c}\text { Public Transport } \\
\text { lines }\end{array}$ & M2/inhabitants & M2/inhabitants \\
\hline 7 & Comp. Belgrano & 27.90 & 0.64 & 41 & 5 & 8.75 & 0.4 \\
\hline 15 & $\begin{array}{l}\text { Milénica B. San } \\
\text { Salvador }\end{array}$ & 29.00 & 1.1 & 45 & 3 & 16.8 & 6.5 \\
\hline
\end{tabular}


in the other by 58 houses arranged in a cloister with blocks of 4 and 3 floors in height. The densities are approximately similar: 150 and 158 dwellings per hectare in each case. The similarities in the final valuation of the RQI obtained in these proposals that differ in their size and in the formal organization correspond to the relatively similar values they present in the dimensions of $\mathrm{m}^{2}$ of residential area per inhabitant ( 29 and $27.9 \mathrm{~m}^{2}$ respectively); and also similar distances to central area in minutes, (45 and 41 minutes). The rest of the values considered, although they are different for each proposal they are compensated in the final weight of the equation.

Note the case of the Example \# 9 "Carlos Tejedor", (Table 5) which presents the most unfavorable value of the RQI.

It is a housing complex of public production, very dense (218 dwellings/hectares) and is composed of a small number of housing units (42) in 7 blocks of 3 floors in height. The parameters that strongly affect the low residential quality are the small residential area per inhabitant $\left(13.9 \mathrm{~m}^{2}\right)$, no parking space; and the low value of the area of open spaces per inhabitant. The indicators of mobility and accessibility, although present middle values, given their lower incidence in the equation weighting, are not enough to compensate for the negative valuations present in the other dimensions mentioned above.

In the case of examples \# 1 and \# 4 (Table 6 ), similar values of the RQI (0.47 and 0.46 ) were obtained, being located in an average range if we consider that

Table 5. Example \# 9, lower RQI value. Own elaboration.

\begin{tabular}{|c|c|c|c|c|c|c|c|}
\hline \# & DATA & & PLOT & DWELLINGS & INHABITANTS & DENSITY & RQI \\
\hline & $\begin{array}{c}\text { Name of housing } \\
\text { complex }\end{array}$ & Year & Area (hectares) & $\begin{array}{l}\text { Number of } \\
\text { dwellings }\end{array}$ & $\begin{array}{l}\text { Number of } \\
\text { inhabitants }\end{array}$ & Dwellings/hectares & \\
\hline \multirow[t]{3}{*}{9} & Conj. Carlos Tejedor & 2001 & 1.922 & 42 & 204 & 218 & 0.20 \\
\hline & & RESIDENTIAL AREA & PARKING SPACES & MOBILITY & ACCESSIBILITY & OPEN AREAS & GREEN AREAS \\
\hline & Indicators & M2 /inhabitants & $\begin{array}{c}\text { Parking/housing } \\
\text { index }\end{array}$ & $\begin{array}{l}\text { Distance in } \\
\text { minutes }\end{array}$ & $\begin{array}{c}\text { Public Transport } \\
\text { lines }\end{array}$ & M2/inhabitants & M2/inhabitants \\
\hline 9 & Conj. Carlos Tejedor & 13.90 & 0 & 39 & 4 & 4.78 & 3.87 \\
\hline
\end{tabular}

Table 6. Example \# 1 \& \# 4 similar RQI values. Own elaboration.

\begin{tabular}{|c|c|c|c|c|c|c|c|}
\hline$\#$ & DATA & & PLOT & DWELLINGS & INHABITANTS & DENSITY & RQI \\
\hline & $\begin{array}{l}\text { Jame of housing com- } \\
\text { plex }\end{array}$ & Year & Area (hectares) & $\begin{array}{l}\text { Number of } \\
\text { dwellings }\end{array}$ & $\begin{array}{l}\text { Number of } \\
\text { inhabitants }\end{array}$ & Dwelling/hectares & \\
\hline 1 & Hogarpropio & 1976 & 11.831 & 112 & 381 & 95 & 0.47 \\
\hline \multirow[t]{3}{*}{4} & La inmobiliaria & 1997 & 8.137 & 60 & 192 & 73 & 0.46 \\
\hline & DIMENSIONES & 1 & 2 & 3 & 4 & 5 & 6 \\
\hline & Indicadores & M2 /inhabitants & $\begin{array}{l}\text { Parking/housing } \\
\text { index }\end{array}$ & $\begin{array}{l}\text { Distance in } \\
\text { minutes }\end{array}$ & $\begin{array}{c}\text { Public Transport } \\
\text { lines }\end{array}$ & M2/inhabitants & M2/inhabitants \\
\hline 1 & Hogarpropio & 21.50 & 0.41 & 36 & 4 & 25.5 & 22.9 \\
\hline 4 & La inmobiliaria & 15.30 & 0.93 & 47 & 6 & 34.8 & 23.45 \\
\hline
\end{tabular}


the maximum theoretical value of the ICR is calculated in 0.85 . Both are publicly owned and were built in the 1970s and 1990s respectively. They are integrated with 112 houses in the case of \# 1 "Hogar Propio", in 3 blocks of 4 floors in height; in the case of \#4 "La Inmobiliaria" the 60 dwellings are distributed in 3 blocks of 3 floors in height. The density values correspond to 95 and 73 dwellings per hectare respectively.

The values of the RQI, for these housing complexes are located in a relatively good range, with respect to the values obtained if we consider the total of cases (surpassing even some more recently constructed), which indicates that these architectural proposals have spatial quality in the design.

When disaggregating the values obtained in the different analytical dimensions considered, it is observed that they exceed the median values of the cases of study composed by 15 housing complexes ${ }^{12}$, most of the indicators are favorable, which explains the high value of the RQI obtained to these values of density. In the case of \# 1, the values of the dimensions considered (except for Dimension 2: parking index per household) exceed the average obtained in the cases study. The same happens with example \# 4 except for Dimension 1: $\mathrm{m}^{2}$ of residential area per inhabitant where the value obtained of $15.3 \mathrm{~m}^{2}$ per inhabitant is lower than the average.

\section{Research Conclusions and Future Challenges}

The analysis of data and the systematization of the results allowed us to verify the validity of the densification levels in the residential complexes analyzed in terms of the relationship between the spatial-criteria adopted in their design and the quality of life they offer, the facilities in terms of access to urban mobility, availability of parking space, and open areas for collective use in the housing complexes, among other dimensions considered in a first stage.

A first cross-linking of the cases studied shows that the existing densification levels are not directly related to the availability of the plot size or the urban location of the complexes. The urban-architectural typology responds to particular intervention criteria adopted at different historical moments (towers, strips, blocks), observing that density has not been considered as an intervention variable when planning residential complexes in the case of Cordoba City. On contrary, as the analysis shows density is a value that is deduced once the housing complexes are built. However, it is a useful tool when comparing different models of spatial organization and their consequences on the resulting residential quality.

The simulation applied to determine the RQI has allowed incorporating the analysis of the complexity derived from the simultaneous handling of dissimilar and opposite variables considered in the six dimensions. It is a useful tool to compare different architectonical proposals and to determine values of residen-

${ }^{12}$ These are: -Dimension 1: $21 \mathrm{~m}^{2}$ of residential area per inhabitant; -Dimension 2: the parking rate per dwelling is 0.5; -Dimension 3: 43 minutes to reach the center; -Dimension 4: 4 public transport bus lines; -Dimension 5: $16 \mathrm{~m}^{2}$ of open space per inhabitant and -Dimension 6: $11 \mathrm{~m}^{2}$ of green space per inhabitant. 
tial quality implicit in each urban form adopted. The rationality and objectivity inherent to the model, the flexibility to incorporate variations that can come from exogenous changes to the problem, the management of inter-discipline, among other aspects, are seen as advantages when applying the methodology and evaluating the results.

The analysis made possible to verify that, residential quality values are independent of the building density and, in high, medium or low densities; there may be situations of good or poor residential quality. This finding implies that in order to achieve conditions of urban efficiency, vitality and residential quality in the planning of future interventions oriented to a greater densification in the urban form, it is necessary to establish architectural-urban design parameters that guarantee good habitability conditions, independently of the formal model adopted. As the analysis shows, there are housing complexes with the same density, and similar RQI values and completely different urban patterns in terms of their volumetric resolution and architectural criteria.

Future challenges

Density is a useful concept when planning new residential areas to propose the number of dwellings or inhabitants that can be housed in a given area. However, as the analysis demonstrates, it is a relative concept that must be considered together with other design variables, to establish specific guidelines to be achieved in the construction of new housing environments.

The case studies presented a wide range of values, depending on different design criteria applied in a long period of time, and also revealed the inexistence of common values in the different indicators considered in the design of collective housing. We mentioned that even if the same density values are present in certain housing complexes, the residential quality conditions may vary according to the design decisions of the spatial organization, and other parameters of a subjective nature related to the culture and social acceptance from different social groups, and conceptions and preferences on densification levels. For a policy to planning more dense environments it is necessary to socially agree, which is the range of values that should be observed in the design-indicators of collective housing, to ensure residential quality standards.

In the present article, some dimensions have been addressed (such as: per capita residential area independent of the typological resolution, the provision of indoor and outdoor parking spaces per housing units, the dimensions of common open (or green) areas in $\mathrm{m}^{2}$ per inhabitants, and others related to the urban location, distance to centrality and facilities to be mobilized by public transport. However, the future challenges in line of research refer to incorporate more complexity to the model, as for example with qualitative variables in the analysis of residential patterns and a new modeling that links it with the proposed densification levels. By this way, going deep in new lines of research brings complexity and diversity to the development of sustainable urban densification models.

\section{References}

Burgess, R. (2001). The Debate on Compact City Policies in Developed Countries. In A. 
Falú, \& M. Carmona (Eds.), Globalización, forma urbana y gobernabilidad : Tercera Conferencia Internacional Red ALFA-IBIS (pp. 47-71). Córdoba: Secretaría de Ciencia y Tecnología, Universidad Nacional de Córdoba, Argentina and Delft: Departamento de Gestión y Renovación Urbana, Facultad de Arquitectura.

De Mattos, C. A. (2001). Metropolización y suburbanización. EURE, 27, 5-8. https://doi.org/10.4067/S0250-71612001008000001

Indovina, F. (2004). La ciudad difusa en Ramos Angel Martín (ed) Lo Urbano. 20 autores contemporáneros. Ed UPC.Pg 230.

Malavolta, A. R. (2007). Il tema della densità nella città contemporanea. Camerino: School of Advanced Studies, Universita di Camerino.

Marengo, C., \& Elorza, A. (2014). Tendencias de segregación residencial socioeconómica: El caso de Córdoba (Argentina) en el período 2001-2008 [versión electrónica]. EURE, 40, 111-133. https://doi.org/10.4067/s0250-71612014000200006

Marengo, C., Ochoa, A., \& Ambrosini, A. (2015). Modelos de densificación residencial: Hacia un desarrollo urbano más compacto. In E. E. Fernandez, M. Marchisio, \& A. Bisceglia (Eds.), Encuentro; II Encuentro de Investigadores que estudian la ciudad. Debates y avances conceptuales para la construcción de la agenda urbana (pp. 21-47). Córdoba: IPLAM-Ciudad (Municipalidad de Córdoba).

Marengo, M. C., Ochoa, A., \& Ambrosini, A. (2015). Comparative Evaluation of Indicators of Density and Residential Quality in Collective Housing Complexes. In G. Badennes, \& A. Marin (Eds.), Proceedings X Biennial of the Colloquium of Territorial Transformations (pp. 1299-1313). Córdoba: National University of Córdoba. https://rdu.unc.edu.ar/handle/11086/1945

Marengo, M. C. (2015). Sprawl and Density, towards a Dispersed Urban Form-The Case of Córdoba City. Argentina Journal of Engineering and Architecture, 3, 45-56.

Newman, M. (2005). The Compact City Fallacy. Journal of Planning Education and Research, 25, 11-26. https://doi.org/10.1177/0739456X04270466

Ramos, J. (1985). Planificación urbana y regional(226 p.). Córdoba: FAUD-UNC.

Shlomo, A., Jason, P., Civco, D. L., \& Alejandro, B. (2010). La persistente dec-linación en las densidades urbanas.

http://www.lincolninst.edu/pubs/1834_The-Persistent-Decline-in-Urban-Densities

Scientific Research Publishing

\section{Submit or recommend next manuscript to SCIRP and we will provide best service for you:}

Accepting pre-submission inquiries through Email, Facebook, LinkedIn, Twitter, etc. A wide selection of journals (inclusive of 9 subjects, more than 200 journals)

Providing 24-hour high-quality service

User-friendly online submission system

Fair and swift peer-review system

Efficient typesetting and proofreading procedure

Display of the result of downloads and visits, as well as the number of cited articles

Maximum dissemination of your research work

Submit your manuscript at: http://papersubmission.scirp.org/

Or contact cus@scirp.org 